NBER WORKING PAPER SERIES

IS THE U.S. A SPENDTHRIFT NATION?

Robert E. Lipsey

Irving B. Kravis

Working Paper No. 2274

NATIONAL BUREAU OF ECONOMIC RESEARCH 1050 Massachusetts Avenue

Cambridge, MA 02138

June 1987

We are indebted to the American Council of Life Insurance and to the Conference Board for support, to Linda Molinari for statistical work and programming, and to James Hayes and Rosa Schupbach for preparation of the manuscript. The research reported here is part of the NBER's research program in International Studies. Any opinions expressed are those of the authors and not those of the National Bureau of Economic Research. 
NBER Working Paper \#2274

June 1987

Is the U.S. a Spendthrift Nation?

ABSTRACT

The belief that the U.S. is a nation of spendthrifts, unwilling to provide for the future, rests on observations of particular narrow definitions of capital formation, on the use of nominal values that ignore international differences in the relative prices of capital goods, and on concentration on the ratio of capital formation to total output rather than on the amount of capital formation per capita.

By a broad definition of capital formation, the U.S. has been investing a proportion of its gross output in the last decade and a half that is not far below that of other developed countries, even in nominal terms. In world prices, or real terms, U.S. capital formation was a higher proportion of output than in nominal terms.

Real gross capital formation per capita in the U.S., even by a narrow definition of capital formation, was above the average for developed countries. By a broad measure of capital formation, few countries surpassed the U.S. in per capita real capital formation.

Robert E. Lipsey

NBER

269 Mercer Street

New York, NY 10003 and

Department of Economics

Queens College

Flushing, N.Y. 11367
Irving B. Kravis Department of Economics 368 McNeil Building University of Pennsylvania Philadelphia, PA 19104 


\section{IS THE U.S. A SPENDTHRIFT NATION?}

\section{Introduction}

Ever since World War II, the U.S. has been thought of as a spendthrift nation - a country that consumes almost all its income and that saves and adds to its capital stock at a low rate, not quite the lowest perhaps, but far down in the standings in the world saving league. Questions have been raised also about the quality of American investment. Americans are thought to have invested relatively large amounts in housing and consumer durables which are supposedly less productive than investments in industry or construction.

If the standard data on the proportion of output devoted to gross capital formation are taken at face value, they show that for the U.S., the ratio of gross capital formation to GNP since 1960 has not differed much from that of the period 1860-1938; it was 19.0 per cent in the earlier period and 17.9 per cent in the later one (Table 1).

For the 40 years or so before 1910, and still during the period between the two World Wars, the U.S. ranked very high in the proportion of output devoted to capital formation in the conventional sense. of 10 developed countries studied by Kuznets (1966), the U.S. had the highest investment rate (gross domestic capital formation relative to GNP) in the 1870's and 1880's, the second highest in the 1890's and 1900's, and the third highest in 1909-1929. By the 1950's, however, the U.S. had next to the lowest rate, ahead only of the U.K. Later decades found the U.S. still at the bottom of this 1ist, in a tie with the U.K. At the other end of the distribution, Japan 
Table 1

Gross Fixed Capital Formation as Percent of GNP, Ten Countries Pre-Wor Id War II and Post-Wor ld War II

Gross Fixed Domestic Capital Formationa

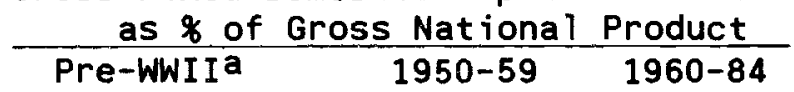

$\frac{\text { Ratio: }}{\text { 1950-59/ } 1960-84 /}$

U.S.

$19.0(1869-1938) \quad 17.9$

17.9

.94

.94

Australia

$16.3(1861-1938 / 39) 28.6$

25.4

1.75

1.56

Canada

$19.9(1870-1930)$

25.0

22.4

1.26

1.13

Japan

$12.9(1887-1936)$

29.4

31.9

2.28

2.47

Denmark

$11.7(1870-1930)$

18.9

22.2

1.62

1.90

Germany

$17.9(1851-1928)$

23.7

23.1

1.32

1.29

Italy

$12.6(1861-1930)$

20.8

20.5

1.65

1.63

Norway

$14.0(1865-1934)$

29.9

29.4

2.14

2.10

Sweden

$12.7(1861-1940)$

21.2

22.0

1.67

1.73

U.K.

$8.6(1860-1929) \quad 15.5$

18.2

1.80

2.12

a Average of sub-period rates weighted by lengths of sub-periods. Although the spans of the periods called "Pre-WWII" vary, they generally include some part of the late 19th Century and the period in the 20th Century up to the late $1930^{\prime} \mathrm{s}$.

Source: Pre-WWII and 1950-59: Kuznets (1966), Table 5.3 1960-84: OECD National Accounts, 1960-1984, Vol. I. 
devoted the highest proportion of its output to capital formation.

The U.S. apparently fell from saving leader to saving laggard because the ratio of gross capital formation to total output changed little in the U.S. between the pre-WW II years and the later period, while it increased in every other couritry, including even the U.K. Since the 1960's, the United States and the United Kingdom have had the lowest capital formation ratios. However, the rough constancy in the U.S. ratio was unique; the closest was the Canadian ratio which has been only a little more than 10 per cent above the pre-WW II leve1. In the other countries, the ratio rose by at least a third, and they more than doubled in a couple of cases. Thus, in the decades following WW II, even relatively low-saving countries have invested more of their incomes in fixed capital than formerly high-saving countries such as Canada and the U.S. had invested in the past.

\section{Finding a Yardstick to Measure Saving and Investment}

The usual picture of the current, or recent standing of the U.S. as a saver is based on the personal saving rate: saving by individuals as a per cent of disposable personal income, the saving rate regularly reported by the Department of Commerce and widely publicized. The comparison for this type of saving can be summarized in the fact that over the decade 1970-1980 the U.S. household saving rate was less than two thirds of the average in eight other OECD countries for which roughly comparable data could be obtained (Table 2 ). As can be seen from the table, it makes a considerable difference whether we look at national saving or household saving and whether we look at gross or net saving.

We have followed Kuznets and other writers in using gross rather than 
Table 2

International Comparison of Saving Rates, 1970-80

Published Estimates Without Adjustments

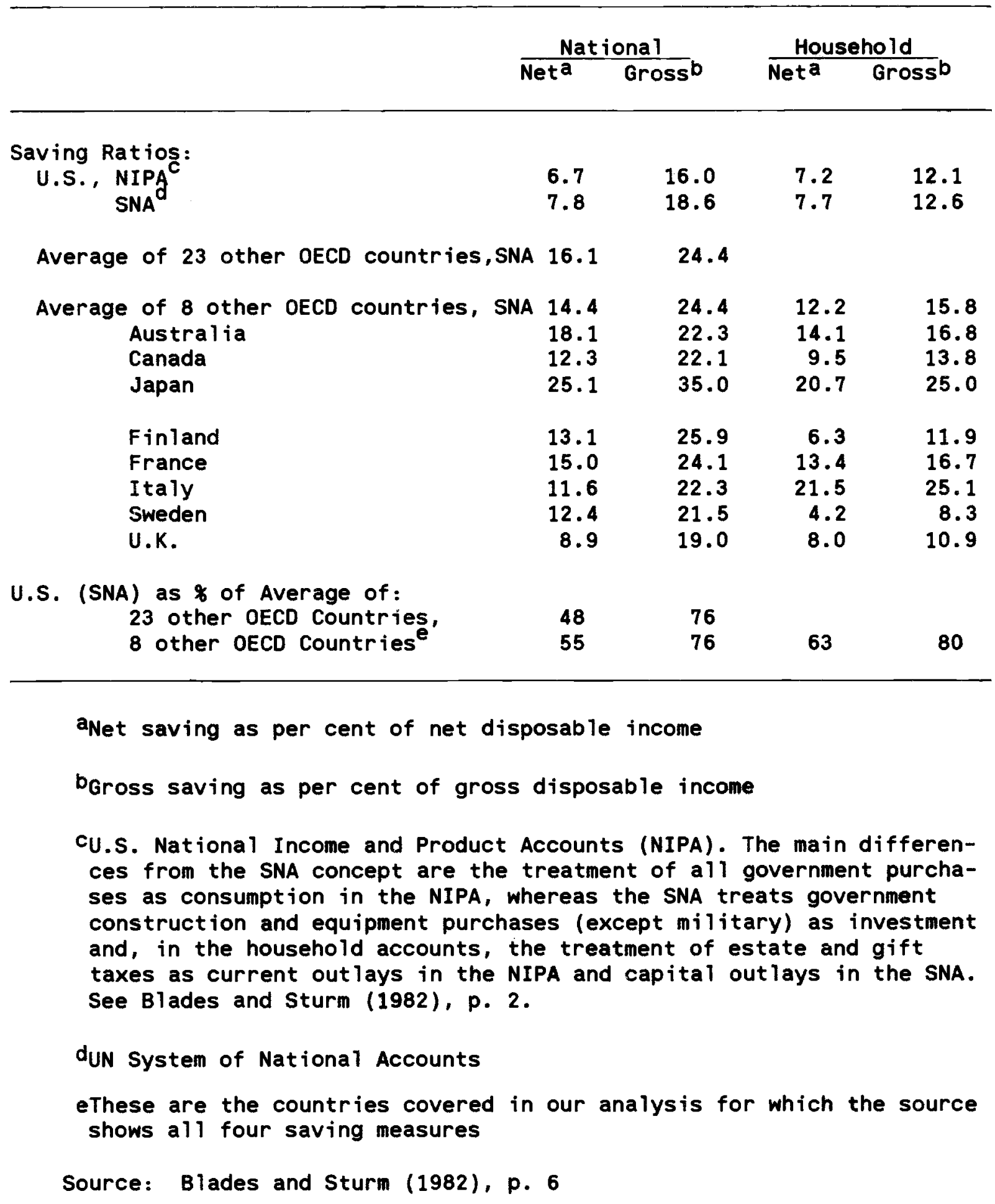


net saving and capital formation. There are several reasons for that choice. One is skepticism regarding available measures of capital consumption, and particularly their comparability among countries (Blades and Sturm, 1982). For example, Hayashi (1986) points out that Japanese depreciation is calculated on the basis of historical cost and that the adjustment to a replacement cost basis amounted to as much as 30 per cent of reported private saving in some years. Another reason for the use of gross measures is the belief that the introduction of new capital equipment brings new technology into the production process, whether or not the new equipment is nominally a replacement for old equipment embodying past technology. If technology, rather than the "volume" in some sense of capital equipment, is what drives economic growth, it is the gross rather than the net capital formation that is relevant for explaining growth. A country in which gross capital formation was equal to calculated depreciation, and therefore resulted in no net capital formation, would nevertheless reap economic growth from the substitution of new technology for old technology.

Turning from the statistics of capital formation to the data on saving, 1 we find that all measures here show the U.S. saving rate to have been low in the 1970's by comparison with that of other countries. That is particularly the case for net saving. Among 24 OECD countries the U.S. was the lowest on net (48\% of the average of the others) and gross (76\%) national saving. Gross and net household saving data are available for fewer countries. As compared with 8 other countries that Blades and Sturm examined more closely and for which household saving rates were available, the

1 In the OECD accounts that we use in this paper the sum of domestic capital formation and net foreign investment is defined to be equal to domestic saving. We focus on domestic capital formation in our calculations, but alternate between that concept and domestic saving in com- 
U.S. national net saving rate was $45 \%$ below the average while the gross was only $24 \%$ below. The difference was smaller for the household saving rate, $37 \%$ on net, $20 \%$ on gross.

For several reasons we focus on aggregate private or national saving, rather than household saving, for our international comparisons. One reason is that the household data are too inaccurate in each country and raise more problems of international comparability than the aggregate private or national data. Another is that there is evidence of substitution between household saving, business saving, and at least the social insurance part of government saving. A third is that for explaining economic growth, aggregate saving and investment are more relevant than the saving of any single sector.

In addition to the economic significance of national as compared with household saving, there is good reason to believe that the national saving data, while subject to many problems of measurement, are more accurate than household saving measures. The national data are protected in a sense by the availability of a control total: aggregate domestic saving must, by definition, equal aggregate domestic capital formation plus net foreign investment, the estimates for which merit more confidence. There is no such independent and relatively reliable check on estimates of the saving of any single sector.

parisons with other studies, ignoring the difference between them, net foreign investment.

By and large, long-run trends in domestic saving and domestic capital formation are similar for most countries over most periods. Similarly, the ranking of countries by saving rates is close to their ranking by capital formation rates. We do, therefore, draw inferences about one from the other at times, but we do point out some differences between the saving and capital formation measures, particularly in discussing recent events in the U.S. 
Broad Measures of U.S. Saving or Capital Formation

Aside from the issue of whether to measure saving gross or net of capital consumption, touched on earlier, the major issue in measurement is the distinction between current expenditures and capital expenditures. What kind of expenditures should be categorized as yielding income beyond the current period?

Broad measures of investment, and correspondingly broad output measures, have been calculated for the United States by Kendrick (1976) and Eisner (1985). 2 Both authors include in investment such items as investment in human capital, including education, on-the-job training, child rearing costs, and costs of labor mobility and migration, investment in tangible household capital, such as durable consumer goods, and investment in intangible capital such as research and development. Kendrick's adjustments to the conventional NIPA measure for the United States (as available to him at that time) raised the estimated share of gross investment in GNP as follows:

\section{9}

1969

Official Estimate,

U.S. Dept. of Commerce

16.5

14.8

Kendrick

43.7

49.5

Source: Kendrick (1976), Tables 3-2 and C-1.

Not only was the 1969 level more than tripled but the decline in the ratio between 1929 and 1969, shown in the official data, was reversed.

Eisner's alterations to the official U.S. accounts apply only to the

\footnotetext{
${ }^{2}$ Some alternative calculations of household saving and different views on its correct measurement can be found in Auerbach (1985) and Hendershott and Peek (1985).
} 
years after World War II but the story they tell of much higher levels of saving and capital formation than in the official records is similar (Table 3 ). Eisner's concept of capital accumulation includes semidurables with durables as a form of investment and, more important, includes net real capital gains and losses. The latter addition makes the series much more volatile relative to GNP. If we exclude the revaluations and investment in household semidurables, the modified Eisner estimates are still at least twice as high as the official ones over most of the period. They show a rising trend through the 1960's and approximate stability after that.

Perhaps the most radical restructuring of national accounts encompassing the widest range of investment in human capital is that in Jorgenson and Pachon (1983). This calculation includes imputations for the value of time spent in schooling not only during working age but also before working age. Furthermore, the value of time spent in schooling is calculated from the increment in lifetime earnings rather than from the value of foregone earnings in the labor market. The estimates included values of human capital based on lifetime earnings for those born in each year and for immigrants. The results of these calculations are:

\section{$\underline{1950-59} \quad \underline{1960-69} \quad \underline{1970-73}$}

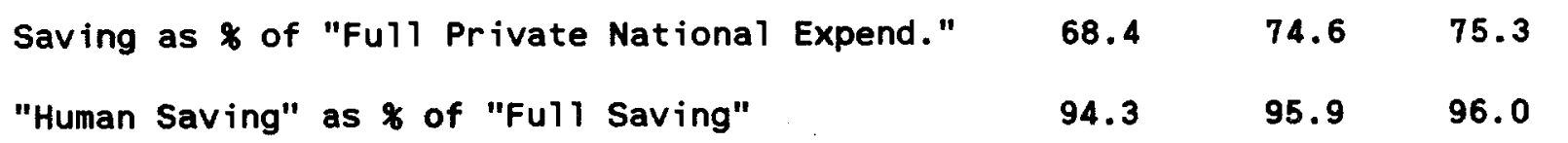

In other words, private saving in the U.S. has been more than two thirds of private expenditures through the postwar period and rose to about three quarters in the 1960's and 1970's. Thus, by these measures, the private economy of the United States was consuming less than a third, and later less than 
Table 3

Comparison of Eisner and Conventional Measures of

U.S. Capital Formation and GNP

(Unit sbillion)

\begin{tabular}{|c|c|c|c|c|c|}
\hline & 1946 & 1956 & 1966 & 1976 & 1981 \\
\hline \multicolumn{6}{|l|}{ Eisner } \\
\hline $\begin{array}{l}\text { Gross domestic capital accumulation } \\
\text { GNP }\end{array}$ & 31.8 & 283.6 & 498.3 & $1,360.4$ & $1,677.9$ \\
\hline $\begin{array}{l}\text { GNP } \\
\quad \text { Ratio }\end{array}$ & 291.1 & 726.5 & $1,246.8$ & $3,067.2$ & $4,560.1$ \\
\hline Ratio & 10.7 & 39.0 & 40.0 & 44.4 & 36.8 \\
\hline $\begin{array}{l}\text { Net revaluations } \\
\text { Household semidurables }\end{array}$ & $\begin{array}{r}-75.3 \\
19.9\end{array}$ & $\begin{array}{l}27.7 \\
26.7\end{array}$ & $\begin{array}{l}12.0 \\
40.6\end{array}$ & $\begin{array}{r}248.4 \\
82.1\end{array}$ & $\begin{array}{r}-153.7 \\
125.6\end{array}$ \\
\hline $\begin{array}{l}\text { Gross domestic capital accumulation } \\
\text { excl. revaluations and semidurables }\end{array}$ & 86.5 & 229.2 & 445.7 & $1,029.9$ & $1,706.0$ \\
\hline $\begin{array}{l}\text { GNP excl. revaluations } \\
\text { Ratio }\end{array}$ & $\begin{array}{r}366.4 \\
23.6\end{array}$ & $\begin{array}{r}698.8 \\
32.8\end{array}$ & $\begin{array}{r}1,234.8 \\
36.1\end{array}$ & $\begin{array}{r}2,818.8 \\
36.5\end{array}$ & $\begin{array}{r}4,713.8 \\
36.2\end{array}$ \\
\hline$\frac{\text { Conventional (BEA) Ratio: }}{\text { (Gross Private Domestic Investment/GNP) }}$ & 14.6 & 16.8 & 16.6 & 15.0 & 16.1 \\
\hline
\end{tabular}

Source: Eisner (1985) 
a quarter, of its income. Saving and capital formation as conventionally defined were an almost negligible part--less than 5 per cent--of total private saving and capital formation.

\section{International Comparisons of Saving and Capital Formation on a Broad Basis}

Unfortunately, broad measures of saving and capital formation have not been calculated on a comparable basis for a large number of countries over long periods of time. The important question for our purposes is whether the use of these broader definitions would raise the calculated saving rate of other countries by similar proportions, still leaving the U.S. a relatively low saver, or whether the ranking of the U.S. as a saver depends on the definition of saving.

In order to answer this question, we experiment with the saving ratios for the 1970s and 1980s, calculating the effects of extending the scope of the saving measure to include provisions for the future that fall outside the conventional national accounting concept of saving. These extensions, and others, have been considered by Kendrick and Eisner in their work on the U.S., but our efforts here are confined to those for which some calculations were available, or could be performed fairly readily, for a considerable number of countries. We draw on the work of Blades and Sturm (1982) and Blades (1983) who had a similar objective and sought also to improve comparability among countries, but we have made our own calculations.

Consumer Durables. The logic of treating households' purchases of consumer durables as capital formation, corresponding to business purchases of durable producers goods, is similar to that for the treatment of house purchases as capital formation in the present systems of national accounts. These goods 
produce services over a long period of time, and the services are, in many cases, very similar to those yielded by the durables bought by business. Cars, the largest item in consumer durables, give transportation service whether they are owned by businesses or by households. Some of those owned by businesses are leased to households for their own use. Refrigerators, freezers, or laundry machinery often provide services to households even if they are owned by businesses. In fact, the distinction between consumer and producer durables in the national accounts rests on ownership rather than function.

To treat purchases of consumer durables as capital formation in the same way as purchases of owner-occupied housing, it is necessary to make two adjustments. One is to add to conventional gross fixed capital formation household expenditures on consumer durables (treated as consumption in both the SNA and the U.S. national income accounts). The second is to add to consumption and output a measure of the current services of consumer durables. This adjustment requires information on the stock of consumer durables and calculations of the services derived from them by consumers. Unfortunately, such calculations are available in detail only for the United States, but we have made some rough estimates of the necessary magnitudes. We have done this by combining OECD data on purchases of consumer durables with Golasmith's estimates of the stock of consumer durables for a number of countries and assuming that missing ingredients of the calculation could be filled in by using the U.S. relationships.

The effect of adding purchases of consumer durables to the conventional measures of capital formation can be seen in the following comparison: 
Per cent of GDP, 1970-84

Conventional Capital Formation incl.
Capital Formation Consumer Durables

U.S.

18.1

23.1

Average of 11 other countries ${ }^{a}$

23.5

27.6

U.S. as 2 of average of 11 countries 77 .

83.

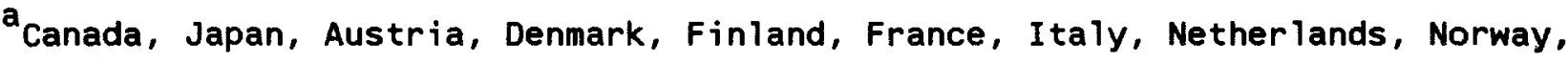
Sweden, U.K.

Source: Appendix Tables 1 and 2

This adjustment alone eliminates more than a quarter of the difference between the U.S. and the other countries. It also compresses the range of saving ratios slightly, since the addition is smallest for Japan and relatively large for the U.S. A possible interpretation of this reduction in the range of rates is that there is some substitution between investment in consumer durables and other forms of saving.

Education. Ideally, we would wish to add to conventional capital formation measures all forms of human capital investment. These would include the earnings foregone by students while they are in school and the costs of on-thejob training. However, such data are not available in any internationally comparable form. The one part of such investment for which we can make calculations for a fair number of countries, and even these require some bold estimating, is expenditures on education. These expenditures yield a return over a long period of time in the form of higher earnings in the labor force. They also probably yield returns in the form of better care of children and greater efficiency in consumption, even after retirement. Some part of the cost of education might more properly be treated as consumption, but any over-estimate of capital formation on that account should be more than balanced by our 
omission of foregone earnings. The effect of making this adjustment alone can be seen in the following:

Per cent of GDP, 1970-84

Conventional Capital Formation incl. Capital Formation Expenditure on Education

U.S.

Average of other 14 countries $^{a}$

18.1

23.3

24.2

28.6

U.S. as $\%$ of average

78.

85.

${ }^{a}$ Same countries as for previous table, plus Australia, Belgium and Germany

Source: Appendix Tables 1 and 3

Once again, the effect of the broadening of the concept of capital formation

is to move the United States somewhat closer to the average of the other developed countries, reducing the gap by more than a quarter.

We can combine the adjustments for consumer durables and education for

only 11 of the 14 countries, because data on consumer durables were not

available for Australia, Belgium, and Germany. The results are only slightly

affected by this limitation, since the average saving rate for the 11

countries, including education expenditures, is only slightly higher than that

for the 14. The effect of the combination of the two adjustments is as

follows:

Per cent of GDP, 1970-84

Conventional Capital Formation incl.
Capital Formation Consumer Durables and

Education

U.S.

Average of other 11 countries

U.S. as $\%$ of average

Source: Appendix Tables 1 and 3
18.1

23.5

28.4

32.8

77.

87. 
Almost half of the apparent gap in investment rates between the U.S. and the other 11 countries is eliminated when we broaden the concept of investment to encompass expenditures on both consumer durables and education.

Research and Development. Research and development is an activity that is probably more forward-iooking than much of investment in equipment and probably includes less current consumption than education. It is thus an even stronger candidate for treatment as capital formation.

Incorporating $R$ \& $D$ expenditures into the measures of capital formation involves, in some cases, an addition to the measure of total output as well. The shift of government and private nonprofit $R \& D$ does not require any adjustment, since they are treated in the SNA and the U.S. NIPA as government and household sector consumption, and therefore as final product. However, business enterprise expenditures on $R \& D$ are treated in these accounts as costs of current production. The shift to treatment of these as capital formation requires that they be removed from current expenditures, raising the level of business enterprise saving and capital formation, and therefore of gross output also. These calculations are described in the Appendix. The effect of adding $R \& D$ expenditures alone is small, since the range is only from 1 per cent to less than $2 \frac{1}{2}$ per cent of GDP, but the result of adding them, along with education expenditures, to gross capital formation is as follows: 


\begin{tabular}{|c|c|}
\hline \multirow{3}{*}{$\begin{array}{r}\text { Per } \\
\text { Conventional } \\
\text { Capital } \\
\text { Formation }\end{array}$} & of GDP, 1970-84 \\
\hline & $\begin{array}{l}\text { Capital Formation incl. } \\
\text { Expenditure on: }\end{array}$ \\
\hline & Education and $R \& D$ \\
\hline
\end{tabular}

U.S.

18.1

26.2

Average of other 12 countries

23.0

29.9

U.S. as $\%$ of average of 12

79.

88.

Source: Appendix Tables 1 and 4

The broadening of the capitat formation concept, as before, substantially

reduces the gap between the U.S. and the other developed countries, now by over 40 per cent. If we add to these two adjustments the inclusion of consumer durables expenditure, as we can do for 10 of the 12 countries other than the U.S., the gap is reduced still further:

\begin{tabular}{cc} 
Per cent of GDP, 1970-84 \\
\hline $\begin{array}{c}\text { Canventional } 1 \text { Formation inc1. } \\
\text { Capital }\end{array} \quad \begin{array}{c}\text { Expend. on Education, } R \& D, \\
\text { Formation }\end{array}$ and Consumer Durables \\
\hline
\end{tabular}

U.S.

18.1

30.1

Average of other 10 countries

23.3

33.9

U.S. as $\%$ of average of 10

78.

89.

Source: Appendix Tables 1 and 4

Half of the gap is eliminated, and the U.S. capital formation rate is only about 10 per cent below that of the other countries.

\section{Military Capital Formation}

It is conventional, and part of both the UN's System of National Accounts and the U.S. National Income and Product Accounts, to treat expenditures on construction and equipment for defense as current government consumption rather than capital formation. Yet, whatever their other faults and virtues, 
and whatever their contribution or lack of contribution to the growth of nonmilitary output, these expenditures are intended to yield output over a long period of time. If we are interested in the extent to which a country sacrifices present consumption for future gains, these expenditures are as relevant as those for civilian consumption.

The inclusion of military capital formation, as we would expect, raises the U.S. saving rate relative to all but one of the other countries for which we can make the comparison, and particularly relative to Japan.

\begin{tabular}{cc} 
Per cent & of GDP, 1970-84 \\
\hline Conventional & Capital Formation incl. \\
Capital & Expenditures on Education, \\
Formation & R \& D, Consumer Durables, \\
& and Military Construction \\
& and Equipment
\end{tabular}

U.S. Average of other 10 countries U.S. as $\%$ of average of 10
18.1

23.3

78
31.4

34.5

91

Source: Appendix Tables 1 and 5

With military capital formation included, the gap between the U.S. and the other developed countries is reduced by about 60 per cent.

Other Adjustments to the Investment Concept. The adjustments we have made bring the U.S. investment ratio from less than 80 to over 90 per cent of those of the other major industrialized countries. There are some further adjustments we did not attempt. One would be to add investment in the form of the foregone earnings of students. A recent estimate puts this item at over 60 per cent of expenditures on education (Johnson, 1985). As the proportion of working-age students attending higher education institutions is higher in the U.S. than in all or most of the other countries, the inclusion of this form of 
investment would raise the U.S. investment rate and bring it closer to the average.

Among other possible adjustments, the inclusion of more of the household economy in the accounts (in addition to owner-occupied housing and consumer durables) would probably raise the denominator (GNP) most for countries with low female labor force participation rates, and thus lower their saving rates relative to countries such as Sweden. The addition of rearing costs to investment, as in Kendrick (1976), would raise saving rates for countries with relatively rapid population growth such as Canada and the U.S., relative to the European countries.

As mentioned above, we have followed, with modifications, some of the procedures of the earlier comparisons in Blades and Sturm (1982) and Blades (1983). However, we have been a little more free, or perhaps reckless, in estimating missing observations. In general, our results confirm theirs despite the differences in method. Both suggest that the more readily feasible adjustments eliminate about half or more of the observed differences between the U.S. and other developed countries in the shares of total output devoted to gross capital formation. That leaves the U.S., as measured, almost 10 per cent below the average of the others, although still low in the ranking: ninth out of eleven in our calculations. And both suggest that the unmeasured items might we 11 erase much of that remaining gap. Similarly, a more recent comparison of household saving rates in the U.S. with those of 5 other developed countries in 1980-82 by the Deutsche Bundesbank (1984) suggested that about half of the difference between the U.S. and the other five, including Japan, and more than half of the difference between the U.S. and the European 
countries, were the consequence of differences in methods of calculating saving.

One can think of shares of saving or capital formation in GDP as measuring some type of investment "effort" or willingness to sacrifice present consumption for future benefits. By a standard that includes both conventional and some non-conventional types of capital formation, the U.S. ranks in the second half of the distribution of industrial countries and is about average for that group.

\section{Expanded Capital Formation} as Per Cent of GDP, 1970-84

U.S. Difference from Average, excl. U.S., of

$\begin{array}{rlc}10 & \text { Countries } & -9 \% \\ 8 \text { Countries, excl. Japan \& Norway } & -5 \% \\ 7 \text { Countries, excl. Japan, Norway, \& Canada } & -3 \% \\ 5 \text { Lower saving countries } & 0\end{array}$

Source: Appendix Table 5

The evidence of these data does not suggest that Americans have been substantially more "present-minded," or neglectful of future needs, than the citizens of most other developed countries.

\section{Real Investment Ratios: How Much Capital Goods Does the Saving of Different}

\section{Countries Buy?}

While the share of total output in current prices may reflect a country's willingness to sacrifice present consumption to increase welfare later, it does not necessarily indicate how much capital is being acquired through that sacrifice. The reason is that capital goods are more expensive relative to other goods in some countries than in others. Capital goods are cheaper rela- 
tive to prices in general in the U.S. than in most other countries.

As between two countries with the same nominal saving or capital formation ratios and equal GDPs, as measured in the usual way in each country's own prices, the one in which the prices of capital goods are low will be setting aside more current output in physical terms for the production of future income; its real capital formation ratio will be higher. Thus, it is to be expected that the U.S. real capital formation ratio will compare more favorably with that of other countries than will its nominal (own-price) ratio. 3

The impact of these differences in price relationships on comparative capital formation ratios is summarized below for 1975 and 1980 , years for which detailed comparisons of prices and real product are available from the UN International Comparison Project for a substantial number of our countries. Ratios of conventionally-defined capital formation to GDP, both measured in nominal prices (based on own-country prices), corresponding to the ratios in earlier text tables, are shown in column 1.

${ }^{3}$ The comparisons here are based on U.S. prices. They are obtained by dividing own-currency expenditures by the purchasing power of the national currency vis-a-vis the U.S. dollar. To shift these to comparisons based on world prices, it would be necessary to multiply each component PPP by the international price, as given in the last column of Table 6.3, pp. 176-179, and Appendix Table 6.3, pp. 208-215, of Kravis, Heston, and Summers, 1982. 


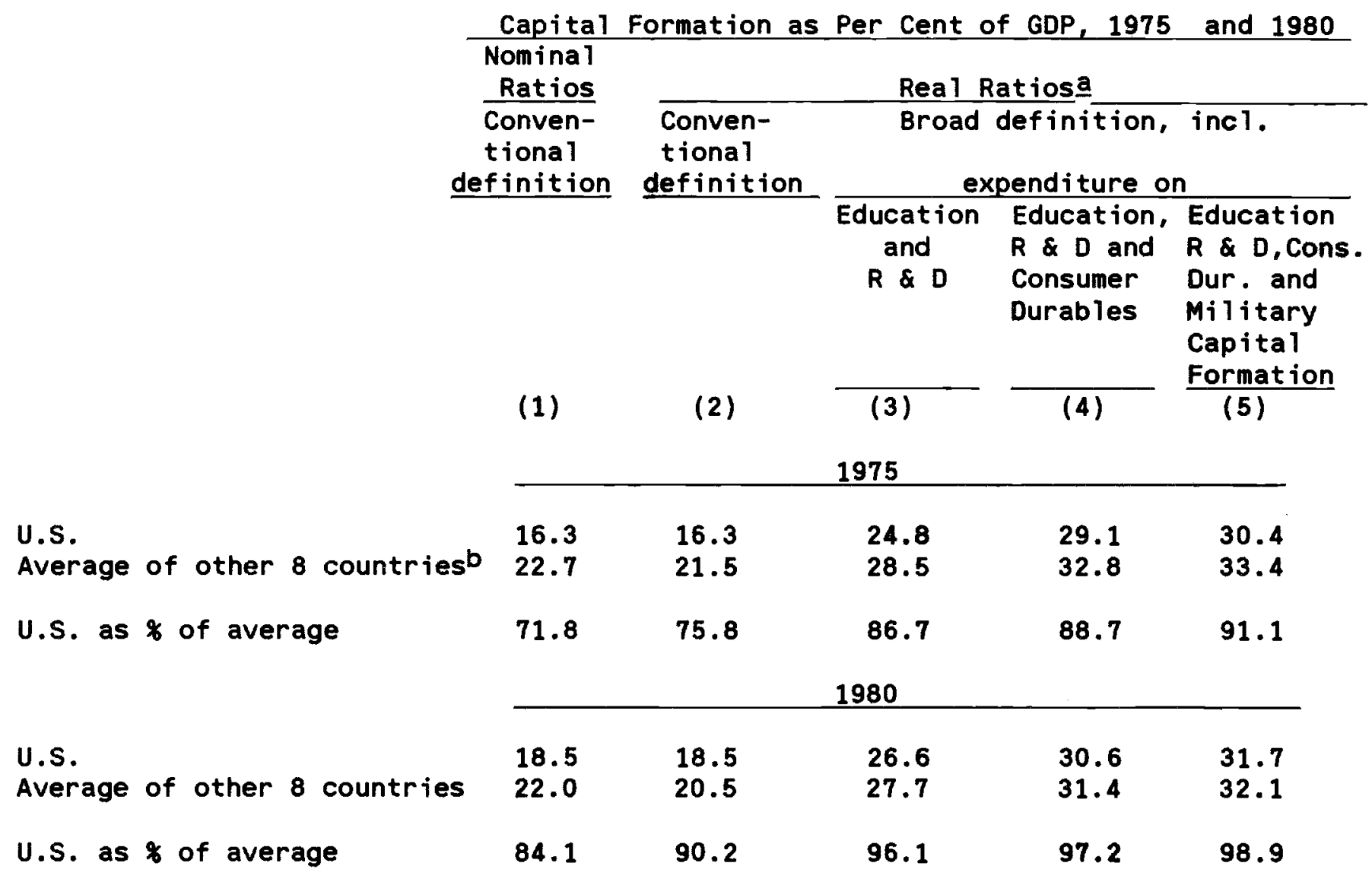

aworld prices used to obtain the real ratios.

bJapan, Belgium, Denmark, France, Germany, Italy, Netherlands, and U.K.

Source: Appendix Table 6

In these two years, the shift to real investment ratios raises the U.S. ratio of capital formation to GDP by 4 and 6 percentage points, relative to the average, to $76 \%$ and $90 \%$ (column 2 ). When the concept of investment is broadened to include other provisions for future flows of goods and services, still retaining the real investment ratio concept, the inclusion of expeditures on education and $R \& D$ reduces the margin between the U.S. and the other seven countries by about half (column 3 ). The further inclusion of spending on consumer durable goods brings the reduction in the difference to more than a 
half. Finally, when we add military capital formation, the U.S. ratio of capital formation to GDP rises to 91 per cent of the average of the other eight countries in 1975 and 99 per cent in 1980.

Among the other countries, shown individually in the Appendix, Japan's real ratio on our most inclusive basis was still the highest, almost 40 to 42 per cent compared to 31-43 per cent for Belgium, France, Germany, and the Nether 1 ands.

Since this comparison is confined to two years and to eight countries, two other points should be noted. One is that 1975 was a particularly unfavorable year for the U.S., to judge from the conventional investment ratios. For the other countries, taken as a group, the investment ratio in 1975 was close to the average of 1970-84, but in the United States it was 8 per cent below the period average. The other is that the comparison with these eight countries shows the U.S. in a less favorable light than the earlier comparisons with 11 or 14 countries. These facts suggest that a comparison of broadly defined investment ratios for the whole period and for more countries would almost certainly find the U.S. close to the average of the other countries.

\section{Per Capita Capital Formation}

When real ratios of capital formation to GDP are compared using a broadened definition of investment, the U.S. climbs a little from the bottom position (the lowest ratio, well below the next lowest) into the lower rungs of the industrial countries in 1975 and to the median position in 1980 (Appendix Table 6). That fact suggests that the U.S. ratio, applied to a higher income than that of most other countries, may entail more real investment per capita than in other countries. 
If we compare the U.S. with the same eight countries on the basis of both conventional and broader concepts of capital formation, the results are as follows :

\begin{tabular}{|c|c|c|c|}
\hline \multicolumn{4}{|c|}{$\begin{array}{l}\text { Capital Formation per Capita, } \\
\text { ș.S. at U.S. Prices: } 1975 \text { and } 1980\end{array}$} \\
\hline Conventional & \multicolumn{3}{|c|}{ Including Expenditure on } \\
\hline & $\begin{array}{c}\text { Education } \\
\text { and } \\
R \& D\end{array}$ & $\begin{array}{l}\text { Education, } \\
R \& D \text { and } \\
\text { Consumer } \\
\text { Durables }\end{array}$ & $\begin{array}{l}\text { Education, } \\
R \& D \text {, Durables } \\
\text { and Military } \\
\text { Capital Formation }\end{array}$ \\
\hline
\end{tabular}
1975

$\begin{array}{lcccr}\text { U.S. } & 1,172 & 1,805 & 2,343 & 2,448 \\ \text { Average of other } 8 \text { countries } & 1,134 & 1,515 & 1,893 & 1,926 \\ \text { U.S. as } \% \text { of average } & 103 & 119 & 124 & 127\end{array}$

$\begin{array}{lcccr}\text { U.S. } & 2,114 & 3,096 & 3,923 & 4,069 \\ \text { Average of other } 8 \text { countries } & 1,978 & 2,701 & 3,283 & 3,347 \\ \text { U.S. as } \% \text { of average } & 107 & 115 & 120 & 122\end{array}$

Source: Appendix Table 6

Real capital formation per capita was higher in the U.S. than it was, on the average, in the other eight countries. Measured on the conventional basis, the U.S. leve 1 was exceeded by those of Japan, Germany, and France in both 1975 and 1980, but on the most inclusive basis, per capita capital formation was highest in the U.S. in both years, a little above that of Germany and Japan in 1980 and about 15 to 17 per cent above them in 1975 (Appendix Table 6).

For the conventional measure of capital formation, some data are available for 1980 covering many more countries, but at OECD prices rather than wor 1dwide prices as in the previous comparisons. If we compare per capita conven- 
tional investment in 1980 for the same 8 countries and for a broader group of 17 OECD countries, we find the following:

\begin{tabular}{c}
$\begin{array}{c}\text { Conventionally Defined Capital Formation } \\
\text { per Capita at OECD Prices: } 1980\end{array}$ \\
\hline$\underline{8 \text { Countries }}$ \\
\end{tabular}

U.S.

100

Average of other countries

84.8

100

U.S. as $*$ of average

118

83.0

Source: Appendix Table 7

The U.S. margin over the other 17 countries in 1980 was a little higher than that over the 8 countries, partly because some quite low income countries were added to the list. Measured in these prices, conventionaliy defined real capital formation per capita in the U.S. was surpassed only in Japan (by 14 per cent) and in Germany (by 7 per cent) among the 8 countries used in the earlier calculations, and in the larger list of countries, by Canada, Luxembourg, and Norway.

On the whole, the evidence points to the conclusion that the U.S. is close to the average of other developed countries in the degree to which it has used its income for forward-looking purposes--capital formation in a broad sense. Since the price of capital goods has been relatively low in the U.S., the ratio of real capital formation, broadly defined, to real output has compared more favorably with that of the other countries than investment ratios based on each country's own relative prices. And since the U.S. is a highincome country, the same fraction of output devoted to investment as in other countries has kept the U.S. investing more per capita than the others on the average, and more per capita than almost all the individual countries. 
Has Low Saving Made the U.S. Poor in Conventional Capital?

We can think of the purpose of saving and investment as being the accumulation of the productive wealth that leads in turn to a high level of production and consumption. A country's wealth at any time incorporates the results of saving over many years. It thus provides a summary of saving history, although wealth can be acquired in other ways, such as by changes in the value of assets already acquired.

Unfortunately, wealth figures are subject to many imperfections, just as saving data are. For one thing, calculations of wealth are almost always many years out of date, Furthermore, records of wealth are kept in each country's own currency, and these must be translated into a common currency for comparison. We do have very complete records of the rate at which at least the major currencies exchange in world markets, but, as has been pointed out, translation by this method does not yield comparability among countries. Exchange rates do not reflect the relative purchasing power of currencies over the stock of physical assets any more than they measure purchasing power over currently produced commodities or services.

If net saving in the United States, conventionally defined, has been low since Wor ld War II relative to that of other developed countries, we might wonder whether the U.S. would by now find conventionally defined capital relatively scarce. Has the U.S. lost its position as the most capital-abundant country? Indeed, that is the picture one finds in some calculations. For example, in one of these, the U.S. appears to have ranked 8 th among 11 developed countries in the amount of capital per person: the U.S. capital per capita was slightly below the average of the other 10 developed countries 
(Appendix Table 8, Col. 1).

There are at least two biases in this calculation. One is that the cumulation of capital expenditures, from which the capital stock is derived, begins in 1950, ignoring all capital available at that time. Since, as we shall see later, the U.S. had far higher capital per person in place in 1950 than most other developed countries, the method understates the stock of capital in the U.S. Secondly, the calculation assumes that a dollar's worth of foreign currency at 1975 exchange rates bought the same amount of fixed capital in each foreign country as a dollar in the U.S. As shown above, a dollar bought more investment goods in the U.S. than did a dollar's worth of foreign currency in other countries.

If we adjust for only the latter bias, we find a different picture of capital abundance. The U.S. real capital stock per person in 1975 was above that of all but three other countries and more than 15 per cent above the average (Appendix Table 8, Col. 2).

We can make some further comparisons for a more limited group of countries, based on a different source and for a different definition of capital stock. This measure omits residential capital, which tends to reduce the U.S. capital stock more than that of most other countries but refers to gross rather than net capital stock, which has the opposite effect. The U.S. appears in these data for the late 1970's to be on a par with Canada and Germany. Japan, France, Italy, and the U.K. appear far less capital-abundant in these calculations.

The largest and most carefully assembled collection of asset (and liability) data from national sources is that of Raymond Goldsmith (1985). 
From these and a set of estimates provided by the OECD, we can make a comparison of capital per person among a dozen countries in the late 1970s and 1980 (Appendix Table 9). Using the conventional measure of net capital stock, we find that the U.S., despite two or three decades of low conventional saving rates, still had in the late 1970 s and in 1980 one of the highest levels of capital per person. It was the highest among the major countries, with the gap remaining very large between the U.S.and the U.K., France, Japan, and Italy. Where both net and gross capital stocks were available from the same source, the gap was larger for gross stocks than for net. It may be that the U.S. capital stock is older than most others, or that it depreciates faster, or that a faster rate of depreciation is used in the U.S. calculations. We are inclined to emphasize the broadest measures of capital we can find (and regret the narrowness even of these) on the grounds mentioned earlier with respect to capital formation. We therefore prefer measures that include at least consumer durables, on the belief that the ownership of a car, for example, by a household does not mean that the car performs services substantially different from those provided by leased cars, taxis or public transportation, although the purchase of a car is not counted as investment and its services are not included in income and output in official calculations.

It is in the high level of consumer capital that the U.S. is most different from other countries. 
Real Net Stock of Consumer Durables, per Capita, Net, Late 1970s

(U.S. $=100)$

$\begin{array}{lr}\text { U.S. } & 100 \\ \text { Canada } & 79 \\ \text { Japan } & 21 \\ \text { Belgium } & 60 \\ \text { Denmark } & 51 \\ \text { France } & 34 \\ \text { Germany } & 68 \\ \text { Italy } & 43 \\ \text { Norway } & 32 \\ \text { U.K. } & 42\end{array}$

Source: Appendix Table 9, Co1. 2

When these are added in to the conventional stock, the U.S. is shown to have had more capital per person than any country except Canada (about equal to the U.S.), and to have led the major industrialized countries by 20 per cent or more (Appendix Table 9).

Although most of these measures show that at least the major foreign countries had not yet caught up with the U.S. in their conventional capital endowments by the mid- or late 1970s, there is little doubt as to the trend. For example, Maddison's presumably consistent measures over the quarter century after 1950 show every country gaining on the U.S. in conventional capital per person. 
Real Conventional Gross Non-Residential

Capital Stock per Capita, 1950, 1960, and 1976

U.S. $=100$

\begin{tabular}{lccc}
\hline & 1950 & 1960 & 1976 \\
\hline U.S. & 100 & 100 & 100 \\
Canada & 78 & 78 & 95 \\
Japan & 17 & 33 & 66 \\
France & 47 & 61 & 81 \\
Germany & 40 & 71 & 80 \\
Italy & 31 & 46 & 54 \\
U.K. & 56 & 65 & 64
\end{tabular}

Source: Appendix Table 10

Al1 these countries except Canada were at least a third below the U.S. in 1950, and all gained on the U.S., even, to some extent, the U.K., a relatively low-saving country. The greatest transformation took place in Japan, of course. Even in 1960, the Japanese level capital stock per person was as far below that of the U.S. as some developing countries have been in recent years. Since 1950, it had been multiplied more than three times relative to that of the U.S. to a level above that of Italy and close to that of the U.K., but still well below France and Germany. The results of the high level of Japanese saving are thus evident in the growth of capital stock but still leave Japan far behind other developed countries, a fact that it is hard to keep in mind in view of Japan's trade performance.

A somewhat different measure of changes over 25 years or so for a smal1 set of partially overlapping countries can be derived from OECD data. 
Real Fixed Capital Stock per Capita Relative to U.S.

\section{Including Residential Excluding Residential

Gross Net Gros N Net

$\begin{array}{ll}\text { Canada } & 1955 \\ & 1964 \\ & 1980 \\ \text { Fin land } & 1970 \\ & 1980 \\ \text { France } & 1955 \\ & 1964 \\ & 1980 \\ \text { Germany } & 1959 \\ & 1964 \\ \text { Greece } & 1980 \\ & 1955 \\ & 1964 \\ \text { Norway } & 1980 \\ & 1964 \\ & 1980 \\ \text { U.K. } & 1955 \\ & 1964 \\ & 1980\end{array}$

$\begin{array}{rrrr} & & 86 & 91 \\ & & 92 & 101 \\ 73 & 78 & 108 & 121 \\ 73 & 78 & 78 & 84 \\ & & 78 & 83 \\ & & 58 & 61 \\ & & 57 & 63 \\ 50 & 55 & 74 & 84 \\ 64 & 79 & 47 & 51 \\ 83 & 93 & 59 & 66 \\ & 21 & 71 & 77 \\ & 33 & & 17 \\ & 43 & & 29 \\ & 99 & & 40 \\ & 114 & & 122 \\ 44 & 43 & 48 & 138 \\ 49 & 51 & 53 & 46 \\ 59 & 63 & 63 & 55 \\ & & & 68\end{array}$

Source: Appendix Table 11

Although there are moderate differences in relative levels of per capita fixed capital where the two sets of data overlap, the direction of change seems clear. In the OECD data also, every country shown increased its per capita stock relative to that of the U.S., whether that stock is measured gross or net or including or excluding residential capital. Thus the relatively low rate of saving in the U.S., conventionally measured, did result in a relatively low rate of growth in capital stock, conventionally measured, but it still left the major industrial countries below the level of U.S. capital per person in 1980 .

Unfortunately, we have little data on stocks of capital outside of conventional capital and consumer durables. We can get some indication of the stock 
of educational capital from data on years of education of various levels. The high level of U.S. capital formation in this form is reflected in the higher average years of formal education in the population, as shown below;

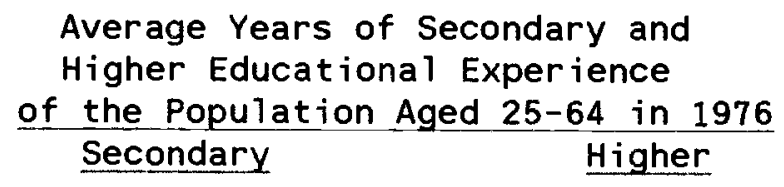

$\begin{array}{lcc}\text { U.S. } & 4.75 & 1.05 \\ 12 \text { other countries } & 3.47 & .445 \\ \text { U.S. as } \% \text { of other } 12 & 137 & 236\end{array}$

Source: Maddison (1982), Table 5.7, p. 110

The stock of educational experience was larger in the U.S. than in the other countries, on the average, and in this respect the U.S. also ranked high--second only to Germany in the stock of secondary education and first, by a long distance, in higher education.

\section{Has the U.S. Misallocated its Capital Formation?}

It is widely believed that the U.S. not only saves relatively little in conventional terms but also funnels excessively large shares of its saving into residential construction and consumer durables, while other countries channel their saving into forms of investment that are regarded as more productive, such as machinery and equipment. We investigate this question with respect to both conventional capital formation and the broader concept and also with respect to the stock of capital.

The question we can answer is whether there are large differences between the U.S. and other countries in the allocation of capital. The question we would wish to answer, ideally, is whether the allocation of capital has been 
so distorted by tax or other preferences that the productivity of capital has been seriously reduced in the U.S. relative to other countries. This question is extremely complex, and involves, among other problems, separating the effects of tax preferences on the allocation of capital by sector of ownership (households vs. business firms) from effects on the type of capital formation (houses vs. factories, or cars vs. machinery). We do not know of any attempts to perform such an analysis across countries and discuss here only the facts about the allocation of capital.

The Distribution of Conventional Capital Formation Among Types of Assets

The share of conventional capital formation going into residential building has not been exceptionally high in the U.S.

\section{Residential Building as Per Cent of Conventional Capital Formation}

$\underline{1960-84} \underline{1960-69} \underline{1970-84} \underline{1970-79} \quad \underline{1980-84}$

\section{U.S.}

14 countries excl. U.S. NA 13 "exc1. U.S. and Sweden

25.6

24.2

$$
26.0
$$

NA

23.2

25.4

26.5

22.7

\section{U.S. as per cent of}

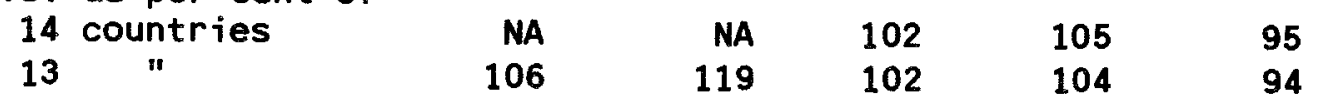

Source: Appendix Table 12

Over the whole period, half of the countries devoted more of their capital formation to residential building. The share in the U.S. was about 6 per cent above the average of 13 or 14 other developed countries, but it was above the average by a large margin only in the 1960's and has been below it for the 1980 's. 
Over the entire 1960-84 period, it was Denmark, Germany, and France that invested most heavily in residential building, and Norway the least. Japan invested a relatively small share in housing during the 1960 's, about 25 per cent below the average of the other countries 1 isted. It moved closer to the average in this respect in the 1970's and 1980's, but remained below average. It should be kept in mind that these ratios represent the cost of building and land improvement but not the cost of land, which is exceptionally high in Japan relative to other costs of housing.

To the extent that rapid growth is associated particularly with high levels of producer durable or machinery and equipment investment, one might expect to find that the U.S. has been neglecting this type of capital formation, while that of the fast-growing countries was heavily tilted in this direction.

\begin{tabular}{ccc}
\multicolumn{2}{c}{ Producer Durables as Per } & Cent of \\
Conventiona 1 & Gross Capital 1 & Formation \\
& $1970-84$ & \\
\hline $\begin{array}{l}\text { Total } \\
\text { Producer }\end{array}$ & $\begin{array}{c}\text { Machinery } \\
\text { and }\end{array}$ & $\begin{array}{c}\text { Transport } \\
\text { Equipment }\end{array}$ \\
Durables & Equipment & \\
\hline
\end{tabular}

U.S.

12 countries exc1. U.S.

42.7

38.8

$\begin{array}{llll}\text { U.S. as per cent of } 12 \text { countries } & 110 & 111 & 106\end{array}$

32.5

29.2

10.2

Source: Appendix Table 13

Again, at least for the last 15 years, the data do not bear out this expectation. The share of producer durables, both transport equipment and other machinery and equipment, in conventional capital formation was above average in the U.S. It was the U.K., a slow-growth, low-investment country 
that had the highest share of capital formation going into machinery and equipment, while the share in Japan was below that of the U.S. and below the average of the other industrial countries.

If we broaden the concept of capital formation to include consumer durables, about half of which are cars, we find some considerable differences in the allocation of investment. The U.S. led in the proportion of investment going into consumer durables, as we might expect from the much-discussed favorable tax treatment of interest on consumer borrowing, only now removed from the federal tax law.

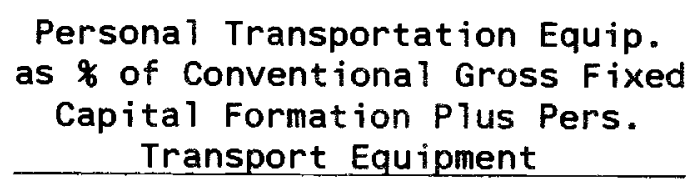

$$
\underline{1960-69}
$$

16.0

8.8

NA

NA

NA

183

NA

NA

NA

\section{0-84}

15.4
Per cent of Conventiona 1 Gross Fixed Capital Formation plus Consumer Durables, 1970-84
Consumer Personal other Durables Transport. Equipment

U.S. as $\%$ of 9 countries

U.S. as $\%$ of 12 countries

U.S. as $\%$ of 11 countries

U.S. as $\%$ of 10 countries

27.2

13.2

14.0

Source: Appendix Table 14

However, the proportion of capital formation going into consumer durables in Canada was the same as that in the U.S. Denmark, France, the Netherlands, and the U.K. were not far behind. The country that allocated very little of its investment to consumer durables was Japan, where the share was under 10 per 
cent, less than half the average of other countries outside the U.S. The United States spent most heavily, by far, on "personal transportation equipment," especially in the 1960's, the share being almost twice the average in 9 other countries. OECD data are not available for Japan, but the ratio must have been low, to judge from the spending on all consumer durables. The high expenditure on personal transportation equipment in the U.S. accounted for all the difference between the U.S. and the other countries in the share of durable consumer goods. In other consumer durables, the U.S. share was no higher than that in other countries.

The Distribution of Broadly-Defined Capital Formation

For the 1970 s and the first half of the 1980 's, we can calculate the distribution, by type of investment, of our broad measures of capital formation.

\author{
Shares (\%) of Each Type of Investment in \\ Broadly-Defined Capital Formation, 1970-1984 \\ Average of U.S. as $\%$ of \\ U.S. 10 Countries Average of \\ (1) exc7. the U.S. $\frac{10 \text { Countr }}{\text { (2) }}$ \\ Source: Appendix Table 15 \\ When we compare the U.S. with the average of 10 other countries, it is \\ clear that conventionally-defined capital formation is a much smaller part of
}


broadly-defined capital formation in the U.S. than in other countries. That is one reason for the large gap between the U.S. and others in the usual comparisons. The U.S. invested a lower share in every conventional form of capital formation and a higher share in each of the non-conventional forms. The U.S. share in construction was particularly low, even compared with the share of its capital formation in non-military producer durables. On the other side, the share of U.S. investment going into $R \& D$ and military capital formation far exceeded that in other countries.

Japan was the only country with more than three quarters of its capital formation in the types of investment conventionally included in national accounts. It is this concentration, particularly on construction, that places Japan so far above other countries in the usual compilations. The other side of the story is the extremely low share of capital formation going into consumer durables in Japan, hardly more than half the share in the next-lowest countries. Japan is also at the bottom of the list in the share of investment going into education, although several other countries are close in this respect. The heaviest investors in $R \& D$ and in military capital formation relative to other forms of investment, were the U.S. and the U.K., also the countries with the lowest shares of investment going into construction. These figures again do not indicate any particularly large share of U.S. capital formation or even of U.S. construction expenditures going into residential construction.

As was noted earlier in comparisons with conventional measures of capital formation, the U.S. had the highest share of investment applied to consumer durables. However, the shares of some other countries were close to the U.S. 
level. If the experience of other countries is any criterion, it is difficult to see in these proportions any enormous distortions in the composition of U.S. capital formation from the favorable tax treatment of consumer interest during these years.

The distribution of capital formation can be different when measured in real values or quantities--that is, quantities valued at a common set of prices for all countries--from what it is in nominal (own-currency) values. The translation via common prices reduces the share of a type of investment that is particularly expensive in a country and increases the share of a type that is relatively cheap. The effect of using real comparisons can be seen in the following: 
Shares in Broadly Defined Capital Formation, Nominal Values and at International Prices, 1975 and 1980

\begin{tabular}{rrr} 
Nominal & Real \\
\cline { 3 - 4 } & $\begin{array}{c}\text { Share in } \\
\text { U.S. as } \%\end{array}$ & Share in \\
of Average & U.S. as \\
of Average
\end{tabular}

\begin{tabular}{|c|c|c|c|c|}
\hline U. & $\begin{array}{l}8 \text { Other } \\
\text { Countries }\end{array}$ & $\begin{array}{l}\text { Share in } \\
8 \text { others }\end{array}$ & $\begin{array}{l}8 \text { Other } \\
\text { Countries }\end{array}$ & $\begin{array}{l}\text { Share in } \\
8 \text { others }\end{array}$ \\
\hline & & 1975 & & \\
\hline
\end{tabular}

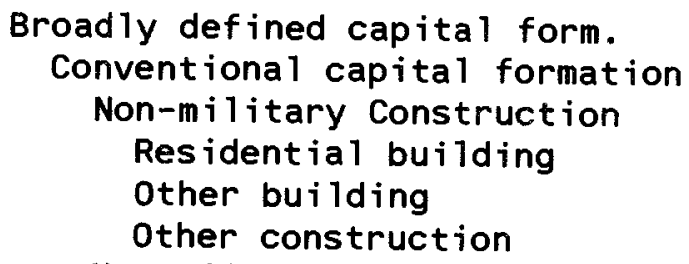

(1)

100.0

47.9

27.8

9.6

8.6

9.6

20.1

(2)

100.0

62.4

38.3

16.5

12.5

9.3

24.1

22.0

18.8

7.0

16.6

14.3

4.7

2.0

4.3
(3)

77

77

73

58

69

103

83

215

\section{2}

131

149

215

Military capital formation

(4)

100.0

59.0

38.1

15.7

9.7

12.6

20.9

19.1

15.8

4.3

1.8
(5)

81

73

61

89

76

96

115

119

163

239

Broadly defined capital form.

Conventional capital formation Non-military Construction

Residential building

other building

other construction

\begin{tabular}{rrrrr} 
& \multicolumn{3}{c}{1980} & \\
\hline 100.0 & 100.0 & & 100.0 & \\
52.0 & 59.1 & 88 & 58.4 & 89 \\
28.5 & 36.4 & 78 & 35.0 & 81 \\
11.0 & 15.6 & 71 & 13.1 & 84 \\
8.4 & 11.9 & 71 & 12.5 & 67 \\
9.2 & 8.8 & 105 & 9.4 & 98 \\
23.4 & 22.7 & 103 & 23.4 & 100
\end{tabular}

Consumer durables

Education

$20.3 \quad 18.3$

$17.2 \quad 15.8$

111

109

$6.9 \quad 4.7$

147

Military capital formation

171

17.3

17.6

117

$3.6 \quad 2.1$

4.6

98

180

Source: Appendix Table 6e

More often than not, the translation into international prices shows the

U.S. to have been closer to the average in the shares of capital formation going into various types of conventional capital formation than the nominal figures suggest, because these types of capital were relatively cheap in the U.S. Two exceptions to the relative cheapness of capital formation in the 
U.S. in both years were non-building construction and education. Shares of both were lower in real terms because these types of investment were relatively expensive in the U.S.

Measured in own-country prices, the share of broadly-defined capital formation devoted to construction was substantially higher in Japan--about half of the total--than in other countries, as can be seen in Appendix Table 6e. But, measured in world prices, that share was not as high; construction was relatively costly in Japan relative to other types of investment. However, the proportion of investment going into non-building construction, mainly infra-structure, was notable in Japan in both years and in Germany in 1975, whichever prices were used.

We noted earlier that the share of producer durables in Japan was not exceptional, but measured in world prices that share was the highest among the countries shown in 1975 and second highest in 1980. Producer durables were cheaper relative to other forms of investment in both Japan and the U.S., so that, measured at world prices, the share of investment the Japanese were devoting to producer durables was above average, and the share in the U.S. was close to the average.

The high proportion of U.S. capital formation allocated to consumer durables, particularly consumer transportation equipment, and to education was noted earlier. The translation to world prices leaves the share allocated to consumer durables in the U.S. about 15 per cent above the average for the other countries. The share in education expenses is cut sharply by measuring it in world prices and is like that of several other countries, because education was extremely expensive in the U.S. relative to other forms of investment. 
The Distribution of the Stock of Capital Among Types of Assets

Another way to examine the allocation of investment is through the distribution of the stock of capital. This can be done using Goldsmith's data for reproducible tangible assets in the late 1970's. The distribution of the stock of capital incorporates not only the cumulation of investment and depreciation over time but also the effects of any differences among the various types of assets with respect to price movements.

The shares of dwellings in reproducible assets, summarized below, reinforce the impressions from shares in capital formation.

$\begin{gathered}\text { Shares in Reproducible Tangible Assets } \\ \text { Late } 1970 \text { 's }\end{gathered}$
Dwellings

U.S.

Australia

Canada

Japan

Belgium

Denmark

France

Germany

I taly

Norway

Sweden

Switzer land

U.K.

12 countries excl. U.S.

U.S. as $\%$ of 12 countries
29.4

21.8

25.1

20.5

34.2

28.1

46.2

32.6

40.6

20.8

31.2

22.5

25.3

29.1

101
11.9

4.1

9.3

5.7

9.5

6.4

6.5

10.3

9.0

3.9

8.3

4.4

9.2

7.2

165

Source: Goldsmith (1985), Table 37

The data do not give the impression that this category absorbed an exceptional share of investment in the U.S. A few western European countries, in particular, had higher proportions of assets in that form. As might be 
expected, the share of dwellings was low in Japan: the lowest among the developed countries. It must be kept in mind, especially in connection with Japan, that 1 and is not included in reproducible assets and in national capital formation, although it does enter the capital formation of individual sectors. Land is extremely expensive in Japan and is a large part of tangible assets: over half as compared with no more than a quarter in any of the other countries recorded (Goldsmith, 1985, Table 37).

Consumer durables play a larger part in U.S. reproducible tangible assets than in those of any other country. These assets were less than half as important in Japan, but there were some European countries where the consumer durables shares were even lower.

We can summarize by saying that the U.S. seems to be at the upper end of the distribution with respect to investment shares in consumer durables but not in homes, while Japan is at the lower end in both groups. If we think of these two assets as producing services directly for households, we find that France and Italy had about half of their reproducible tangible assets performing this role, and the U.S. and most European countries had 35-45 per cent of such assets in that role. At the other extreme, Japan, Australia, Norway, and Switzerland devoted only about a quarter of these assets to such services.

It is important to keep in mind that as far as consumer durables are concerned, they are not the only non-housing assets devoted to providing consumer services. The category is distinguished by ownership rather than by function. Countries with low proportions of consumer durables in their assets may have large proportions of similar types of capital under the category of producer durables if they are owned by business firms rather than by house- 
holds (e.g., consumer durables in rented houses as opposed to those in owneroccupied houses).

\section{Saving vs. Capital Formation}

We have discussed saving and capital formation rates as if they were identical although they differ to the extent that a country is financing its capital formation by borrowing from foreigners or is financing other countries' capital formation by lending to foreigners. We have been able to do this in analyses of long-run developments because, for developed countries, over periods long enough to average out cyclical changes, the two measures are typically very similar. Kuznets $(1966, p .240)$, in discussing trends in the share of capital formation and saving in output, pointed out that the difference was important for only the U.K., among lending countries, and for some of the smal1 borrowing countries in the early stages of development. For the developed countries considered here, the two ratios are very similar, as has been pointed out by Feldstein and Horioka (1980). They reported that for the period 1960-74, the average absolute difference between gross saving and gross capital formation ratios among 21 developed countries was a little over 1 percent of GDP and a little over 5 percent of the saving ratio, 4 percent for the countries we discuss in this chapter. For 1970-79, the difference was about 4 percent of gross capital formation for the 15 countries we cover, but it rose to over seven percent in 1980-84 (Appendix Table 16). Thus, for most periods, and particularly for judging changes over longer spans, it is appropriate to use the saving rate and the capital formation rate interchangeably.

The latest period, 1980-84, shows an unusual degree of divergence between the two, and the absolute amounts, particularly for the U.S., are enormous. 
However, even the 1984 U.S. deficit in the $\$ 100$ billion range was only 2.5 percent of GDP, and the deficit of 1980-84 averaged under 4 per cent of gross capital formation. Half of the countries covered here were borrowing from abroad larger portions of the financing of their domestic capital formation in 1980-84 than the U.S. was.

Gross Capital Formation as Per Cent of Gross Saving 1980-84

$\begin{array}{lr}\text { U.S. } & 104.0 \\ \text { Australia } & \\ \text { Canada } & 121.9 \\ \text { Japan } & 101.7 \\ & 96.8 \\ \text { Austria } & \\ \text { Belgium } & 103.2 \\ \text { Denmark } & 117.5 \\ \text { Finland } & 123.4 \\ \text { France } & 105.7 \\ \text { Germany } & 108.4 \\ \text { Italy } & 100.4 \\ \text { Nether lands } & 107.5 \\ \text { Norway } & 90.0 \\ \text { Sweden } & 88.7 \\ \text { U.K. } & 112.9 \\ & 92.6\end{array}$

Source: Appendix Table 16

The 1984 deficit was, of course, much larger relative to gross capital formation - over 13 per cent. It is that very recent history, and its continuation into the present and the future, that provokes alarm. In judging long-term trends, however, it is important to keep in mind that such deficits have not been typical of the U.S. 
Summary

We have found that, by a broad definition of capital formation, the U.S. has been investing a proportion of its gross domestic product that is not far below that of other developed countries over the past decade and a half. Thus, the U.S. has not been a particularly extravagant nation, although most countries invest larger shares of their output.

The U.S. long run ratio of gross capital formation to GNP, measured by the conventional definition, was about the same before and after World War II. In the earlier period (1869-1938), that ratio placed the U.S. in the front ranks of countries in this respect, but since 1950, the ratios for other countries have risen to higher levels. While the proportion of output devoted to capital formation may have been a little lower in the U.S. than in other countries, the U.S. got more real capital than most countries out of a given amount of investment because prices of capital goods were relatively low in the U.S. Thus, in world prices, or real terms, U.S. investment was higher relative to output than in the nominal terms in which the comparison is usualty made.

If we examine real capital formation per capita, even by a narrow definition of capital formation, the lower U.S. proportion of capital formation in output, combined with the higher U.S. output per capita, resulted in a U.S. investment per capita above that of developed countries as a group. For a broad measure of capital formation, the U.S. margin relative to the average was even larger, and few countries surpassed the U.S.

The results of many years of capital formation, as incorporated into capital stock measures, confirm the impression that the U.S. continues to be rela- 
tively rich in capital. Even by conventional definitions of capital stock or only slightly expanded definitions, the U.S. remained, at the beginning of the 1980 's, as the country with the largest real capital stock per capita. Although a few small countries may have moved ahead of the U.S. in this respect, the major developed countries, and particularly Japan, remained substantially below the U.S. level.

Within the total of capital accumulation the U.S. did not, as is often supposed, devote an exceptionally large share to residential construction or a particularly small share to machinery and equipment. The U.S. did devote a relatively large part of capital formation to consumer durables but again, the real outlier was Japan, in which the share of such investment was very low compared to almost all the other countries. It should be noted that consumer durables are distinguished from producer durables not by their function or by whether they serve the production of consumer goods rather than producer goods, but by the fact of their ownership by households. Some part of producer durables in one country may be performing the same functions, under different ownership, as consumer durables in another country.

Taking the broader view of capital formation, we found that Japan devoted an exceptionally large part of total investment to the conventional forms, particularly to construction, and the U.S. an exceptionally small fraction. That is part of the reason why Japan's capital formation ratio appears so high and that of the U.S. So low relative to other countries when the comparisons are based on the conventional definitions. The U.S. spent relatively large proportions of capital formation on consumer durables, military capital formation, R\&D, and, to a smaller extent, on education. 
What does this record say about the widespread impression that the U.S. is a nation of spendthrifts, unwilling to provide for the future? We conclude that this belief rests on observation of a particular narrow definition of capital formation, on the use of nominal values that ignore international differences in the relative price of capital goods, and on concentration on the ratio of capital formation to total output rather than on the amount of capital formation per capita. By some measures of capital formation we find the U.S. to be similar to other developed countries and by others, above them in the extent to which production is applied to future needs. We do not know which of these measures of capital formation is best related to the prospects for future growth but we know of no basis for assuming that the conventional definition is most appropriate. 


\section{List of References}

Auerbach, Alan J. (1985), "Saving in the U.S.: Some Conceptual Issues," in Hendershott, Ed. (1985).

Blades, Derek W., and Peter Sturm (1982), "The Concept and Measurement of Savings: The United States and Other Industrialized Countries," in Saving and Government Policy, Proceedings of a conference held at Melvin Village, New Hampshire, October 1982, sponsored by the Federal Reserve Bank of Boston.

B lades, Derek W. (1983), "Alternative Measures of Saving," OECD Occasional Studies, Paris, OECD.

Canada Year Book, various issues, Ottawa, Statistics Canada.

Deutsche Bundesbank (1984), "The Saving Ratio of Households in the Federal Republic of Germany: An International Comparison," in Monthly Report of the Deutsche Bundesbank, January.

Eisner, Robert (1985), "The Total Incomes System of Accounts," Survey of Current Business, January, pp. 24-48.

Feldstein, Martin, and C. Horioka (1980), "Domestic Savings and International Capital Flows," Economic Journal, Vol. 90, No. 358, June.

Goldsmith, Raymond W. (1985), Comparative National Balance Sheets: A Study of Twenty Countries, 1688-1978, Chicago, The University of Chicago Press.

Hayashi, Fumio (1986), "Why is Japan's Saving Rate So Apparently High?" in Stanley Fischer, Ed., NBER Macroeconomics Annua 1, 1986, Cambridge, Mass. and London, MIT Press For the National Bureau of Economic Research.

Hendershott, Patrick H. and Joe Peek (1985), "Real Household Capital Gains and Wealth Accumulation," in Hendershott, Ed. (1985).

Hendershott, Patrick H., Ed. (1985), The Level and Composition of Household Saving, Cambridge, Ballinger.

International Monetary Fund (1985), International Financial Statistics, Supplement on Exchange Rates, Supplement Series, No. 9.

Johnson, George (1985), "Investment in and Returns to Education," in Hendershott, Ed. (1985).

Jorgenson, Dale, and Alvaro Pachon (1983), "The Accumulation of Human and Non-Human Capital," in Modigliani and Herring (1963).

Katz, Arnold J. (1982), "The Value of Services Provided by the Stock of Consumer Durables, 1947-79: Alternative User Cost Estimates," in U.S. Department of Commerce, Bureau of Economic Analysis, Measuring Nonmarket Economic Activity, BEA Working Papers, December. 
Kendrick, John W. (1976), Formation and Stocks of Total Capital, New York, National Bureau of Economic Research.

Kravis, Irving B., Alan Heston, and Robert Summers (1982), Wor ld Product and Income, Baltimore, Johns Hopkins University Press for the World Bank.

Kuznets, Simon (1966), Modern Economic Growth-Rate, Structure, and Spread, New Haven and London, Yale University Press.

Leamer, Edward E. (1984), Sources of International Comparative Advantage, Cambridge, MIT Press.

Maddison, Angus (1982), Phases of Capitalist Development, Oxford, Oxford University Press.

Musgrave, John C. (1983), "Fixed Reproducible Wealth in the United States, 1979-82." Survey of Current Business, Vo1. 63, No. 8, August.

(1986a), "Fixed Reproducible Tangible Wealth in the United States," Revised Estimates, Survey of Current Business, Vol. 66, No. 1, January, pp. 51-75.

(1986b), "Fixed Reproducible Tangible Wealth in the United States, 1982-1985," Survey of Current Business, Vol. 66, No. 8, pp. 36-39.

NATO (1985), Nato Review, December.

OECD, National Accounts, various issues and computer tapes, Paris.

OECD (1982), Science and Technology Indicators, Basic Statistical Series Volume B, Gross National Expenditures on R \& D (GERD) 1963-1979.

(1983a) Flows and Stocks of Fixed Capital, 1955-1980, Department of Economics and Statistics, Paris.

(1984), Science and Technology Indicators, Basic Statistical Series, Recent Results, Selected S \& T Indicators, 1979-1984.

(1985), Science and Technology Indicators, Basic Statistical Series,

Volume B, Gross National Expenditure on R\& D, 1969-1982

(1986), Science and Technology Indicators, Basic Statistical Series

Recent Results, Selected R \& D Indicators, 1981-1986.

Stockholm International Peace Research Institute (1979), World Armaments and Disarmament, SIPRI Yearbook 1979, London, Taylor \& Francis Ltd.

(1985), Wor 1d Armaments and Disarmament, SIPRI Yearbook 1985,

London, Taylor \& Francis Ltd.

United Nations, Statistical Yearbook, various issues, New York, United Nations. 
(1966), Demographic Yearbook, 1965, New York, United Nations. (1974), Demographic Yearbook, 1973, New York, United Nations. (1985) Demographic Yearbook, 1983, New York, United Nations.

United Nations and Eurostat (1986), Wor ld Comparisons of Purchasing Power and Real Product for 1980, Phase IV of the International Comparison Project (ICP), United Nations and Eurostat.

(1986), "Selected National Income and Product Est imates, 1929-85," Survey of Current Business, Vo1. 66, No. 2, February.

U.S. Department of Commerce (1986), "Selected National Income and Product Estimates, 1929-85," Survey of Current Business, August.

U.S. Department of Defense (1982), Report on Allied Contributions to the Common Defense, A Report to the United States Congress by Caspar $W$. We inberger, March.

Ward, Michael (1985) Purchasing Power Parities and Real Expenditures in the OECD, Paris, OECD. 